Article

\title{
Impacts of Photovoltaic Farms on the Environment in the Romanian Plain
}

\author{
Alexandra Vrînceanu ${ }^{1}$, Ines Grigorescu ${ }^{2}$, Monica Dumitrașcu 1,*(i), Irena Mocanu ${ }^{3}$, \\ Cristina Dumitrică ${ }^{1}$, Dana Micu ${ }^{1}$, Gheorghe Kucsicsa ${ }^{2}$ and Bianca Mitrică ${ }^{3}$ \\ 1 Physical Geography Department, Institute of Geography, Romanian Academy, 12 Dimitrie Racoviţă Street, \\ Sector 2, 023993 Bucharest, Romania \\ 2 Environment and GIS Department, Institute of Geography, Romanian Academy, 12 Dimitrie Racoviţă Street, \\ Sector 2, 023993 Bucharest, Romania \\ 3 Human Geography and Regional Development Department, Institute of Geography, Romanian Academy, \\ 12 Dimitrie Racoviţă Street, Sector 2, 023993 Bucharest, Romania \\ * Correspondence: stefania_dumitrascu@yahoo.com; Tel.: +40-721-243-489
}

Received: 5 June 2019; Accepted: 27 June 2019; Published: 1 July 2019

\begin{abstract}
Under the European Union (EU) energy efficiency targets that Romania has assumed, increasing the share of solar energy has been one of the main points to be considered. The most important solar energy resources are found in the lowlands and low hills in southern and south-eastern parts of the country. The current paper is focused on the Romanian Plain, which has the best environmental conditions to support the development of photovoltaic (PV) farms. One hundred and ten PV farms have been identified and mapped which cover a total area of 1393 hectares. Although it provides a clean and sustainable energy source, the related environmental implications of PV farms could be either positive or negative. In this study, some of the main categories of impacts have been selected for identification and analysis of their environmental consequences. Several indicators have been computed: the share of PV farms from the main land use/cover categories and main soil types, and the distance of PV farms to forests, water bodies, or protected areas. The overall results of the study reveal the current and potential impacts of PV farms in order to understand the interactions between the environment and the use of renewable energy sources and further support science-based solutions for sustainable development.
\end{abstract}

Keywords: solar energy; photovoltaic farms; environmental impact; Romanian Plain

\section{Introduction}

With increasing global population and economic development, there has been a rising demand for alternative energy options to reduce dependence on limited reserves of fossil fuels and mitigate climate change impacts [1]. Thus, renewable energies (e.g., solar, wind, and biomass) have become alternatives to non-renewable ones. However, their extended use requires an understanding of their environmental interactions in order to better deal with the resulting tradeoffs [2] in terms of land use/cover changes, land productivity, biodiversity, water, and soil quality, etc. The Europe 2020 strategy targets on climate change and energy, also known as the European 20-20-20 targets, seek to reduce Greenhouse Gases (GHG) emissions and increase energy efficiency [3]. In addition to this initiative, the United Nations General Assembly has declared the decade 2014-2024 as the "Decade of Sustainable Energy for All", underscoring the importance of energy issues for sustainable development [4] and encouraging and supporting the extended use of renewable energy resources (RES). As a result, across the European Union (EU), the RES share in gross final energy consumption is expected to increase substantially from $8.1 \%$ in 2005 to $20.6 \%$ in 2020 [5,6], as set out in the 2009/28/EC Directive on the promotion 
of the use of energy from renewable sources [7]. Nevertheless, despite the rapid development of solar power infrastructures and technologies, the European Union market is still in transition and is increasingly oriented to commercial and residential systems that are taking greater advantage of solar power production costs, which are frequently lower than electricity supply prices [8].

Compared to conventional energy sources, solar energy technologies (SETs) provide significant social and environmental benefits, thus contributing to sustainable development [9-11], and have multifaceted impacts that need to be taken into account to promote sustainable development, especially in rural communities [12]. SETs include solar thermal heating, photovoltaic power (PV), and solar thermal electricity [9]. If proper design, planning, and management are applied [11], the electricity produced from SETs provides both environmental (it being a clean alternative to fossil fuels since it generates no greenhouse gas emissions) and socio-economic (e.g., leading to job creation and economic prosperity) benefits to less developed areas [10]. Among SETs, large-scale PV systems generally have lower environmental impacts, with these PV systems being the most viable renewable energy technologies, generating no noise or chemical pollutants during use, reducing greenhouse gas emissions, or providing reuse of marginal lands [11]. Impacts and changes in landscape are likely to occur from the early stages of the construction of systems, being mainly driven by manufacturing and building activities [9,10]. As a result, regardless of the positive implications PV systems have (e.g., cleaner energy production and local level socio-economic development), a large body of literature has been devoted to their negative environmental impacts, covering land use/cover [1,13], biodiversity [14,15], human health [16], or summaries of all of the above $[2,9,10,14,15,17,18]$; visual pollution $[9,19,20]$; and landscape impacts of photovoltaic projects [21].

In this context, the main objectives of the current study were to (1) identify and map all PV farms in the Romanian Plain and (2) to relate the spatial distribution of PV farms to major natural and socio-economic environmental features (land use/cover, soils, forests, roads, and settlements) in order to (3) categorize the main environmental impacts, both positive and negative, and group them into distinct categories (e.g., land use and landscape, ecosystems, environmental quality, and climate change).

\section{Key Driving Forces of Environmental Impacts}

In Romania, the most common solar technologies used for buildings are solar photovoltaic panels, which generate electricity and solar thermal systems that heat water or air. PV farms, which prevail in the Romanian Plain, are large-scale photovoltaic systems designed for the supply of merchant power into the electricity grid. Recent worldwide investigations into PV farm implementation in different areas underline their strong connection with environmental changes. These changes are shaped by key driving forces which are natural or biophysical (e.g., sunshine duration) and anthropic (e.g., EU legislative commitments, national legislation, worldwide events, and national and regional economic and political contexts).

It is obvious that natural factors such as solar radiation, cloud cover, and sunshine duration are the most important driving forces underpinning the development of the solar industry. The economic, financial, legislative, and socio-demographic context also influences the positive, stagnant, or negative dynamics of the renewable energy sector, including that related to solar energy. For this reason, four examples of key driving forces which highlight the ways in which photovoltaic farms impact on environmental factors (e.g., soil, biodiversity, and land use/cover), are detailed in the following sections, with these variables including financial, legislative, socio-demographic, and academic forces.

Firstly, since 2012, the financial situation (e.g., subsidies) coupled with an insecure economic international context (i.e., the recent economic-financial crisis), has made entrepreneurs cautious about investing in the energy sector. As a result, EU documents and reports have stated that renewable energy technology which has been developed has been aimed at flexibility of programs in order to promote renewable energy and reduce subsidies [22]. These guidelines in the field of renewable energy have not been strictly followed in Romania, where the promotion and support of the production of renewable energy has been far too disturbed by a changing legislative framework (e.g., legislation 
on renewable energy production has been modified several times-in 2010, 2011, and twice in 2013, with other changes being carried out during 2016, 2017, and 2018). At the same time, subsidizing the photovoltaic industry by granting Green Certificates (GCs) - tradable certificates that represent the environmental or social benefits of electricity generated from RES (i.e., PV) which can be purchased both from electricity producers and consumers as proof of producing or consuming renewable electricity (www.epia.org) — has strongly influenced investment in the solar industry. Thus, according to Emergency Ordinance No. 88/2011, six CV/MW produced by a photovoltaic system were granted; in 2012, the decision was made to reschedule two CVs to 2017, after which a further rescheduling was made to the end of 2024 with their gradual recovery until $2035[23,24]$. The inconsistency in granting subsidies and legislative instability also affected the $110 \mathrm{PV}$ farms built in the study area. Over $60 \%$ of these farms were installed in 2013 , i.e., before investors were severely affected by economic-financial instability but also by legislative provisions regarding the category of land that is allowed to install a solar park.

Secondly, in terms of legislative framework, EU commitments represent the main and the most important context for the development of the solar energy industry, which has impacted the environment where the PV farms implanted. In addition, national legislation represents a key force, with investors asking for legislation predictability, which Romanian legislation did not provide. The improvement of the legal framework has led to a considerable increase in interest in investment in the renewable energy sector. For example, Emergency Ordinance No. 88/2011, which established a "green" energy support scheme for the next decade, amounting to 10 billion lei, was a signal for the unblocking of projects, financing, and transactions in this economic sector [24]. Starting from 2014, the legislation intended to reduce the number of GCs accredited to energy producers and stated that investors shall not benefit from the support scheme if their solar park is located on cultivable agricultural land $[25,26]$.

Thirdly, low living standards, poverty, lack of education, and an aging population are just a few of the socio-demographic factors influencing the dynamics of the solar industry. For example, without being aware of the possible negative implications of installing a solar park, elderly people and/or those with a low level of education from rural areas have concessioned their land (including arable land) for 50 years for a relatively modest revenue. Cumulated with other behaviors driven by similar socio-demographic factors (e.g., land grabbing) in the Romanian Plain, especially in the Bărăgan Plain, [27] food security in a region or country becomes vulnerable [28].

Nonetheless, the intensive use of solar energy, as the foremost sustainable source, can have negative impacts on the economy and the income of the population. In the case of Romania, the price of energy fell due to incentives, which stimulated cheaper electricity exports to Hungary, Bulgaria, and Serbia, where tariffs are higher. Hence, the Romanian population appeared to sustain the importing states, an important part of the financial support of renewable energy being "exported" by purchasing solar panels from abroad [29].

Solar power in Romania. After joining the EU in 2007, Romania underwent significant changes in the alignment of its energy policy and legislation and promotion of renewable energy, thus becoming attractive for investments $[7,30]$. As a result, energy efficiency became one of the main EU targets Romania assumed towards a greener economy. Moreover, Romania's Energy Strategy for 2007-2020 (updated 2011-2020) has set a key target for 2020 to increase the share of renewable energy in gross final energy consumption to $20 \%$ (EU target) and $24 \%$ (national target). Currently, the country has already reached the 2020 targets and envisages further measures to achieve the new target (32\% by 2030) in accordance with the provisions of the Energy Strategy of Romania for the period 2007-2020 and of the Energy Strategy of Romania 2016-2030, with an Outlook to 2050.

The environmental conditions of Romania support a diversity of renewable sources with significant energy potential. There are five types of RES in Romania-wind, solar, hydro, geothermal, and biomass-whose territorial distribution is related to the main physical-geographic features involved (i.e., relief and climate). The most important solar energy resources are found in the lowlands and low hills in southern and south-eastern Romania, these areas being the Danube Delta, the Dobrogea 
Plateau, and the Romanian Plain [7]. Solar energy, in the form of solar radiation, is an important source of renewable energy but has been insufficiently exploited so far [31]. Currently, it is being exploited through the use of solar active techniques represented by photovoltaic panels and thermal solar collectors. Meteorological parameters such as solar radiation, air temperature, relative humidity, wind speed, cloud cover, and sunshine are generally dependent variables that underlie existing solar power (solar photovoltaic) through estimation and modeling for its exploitation at different spatial scales. Of these variables, solar radiation and sunshine duration are considered key variables (parameters) in highlighting the sun's exploitable energy potential for economic purposes in a region. The degree of solar irradiation in Romania is determined by systematic radiometric measurements by the national meteorological network. At present, these measurements are carried out at nine stations, which, although they cover all geographic regions of the country, have a poor territorial distribution; the stations are at Iași, Cluj-Napoca, Deva, Timișoara, Poiana Brașov, Galați, Bucharest-Afumați, Constanța, and Craiova [32].

Within the EU, Romania has registered one of the highest increases in PV as represented by MW peak, moving from 0 in 2005 to 1,374 in 2017 and being ranked tenth in terms of connected and cumulated photovoltaic capacity amongst European Union countries at the end of 2017. In addition, Romania had a good position (tenth) in terms of electricity production from solar photovoltaic power in 2016 and 2017 (in GWh) and was eighteenth in terms of photovoltaic capacity per inhabitant (W/inh.) for each EU country in 2017 [8]. Moreover, over the 2013-2017 period, of all types of renewable energy, the highest increase was registered by solar power, this being over $800 \%$, even if in the renewable energy mix structure, solar energy is at the bottom of the list $(2 \%)$ after hydropower $(23 \%)$ and wind $(12 \%)$, and only being followed by biomass (1\%) [33]. Almost the same situation is related to electricity production. In 2018 , hydropower had the highest share (29\%), being followed by coal ( $25 \%)$, nuclear $(18 \%)$, natural gas $(15 \%)$, wind $(10 \%)$, photovoltaic $(2 \%)$, and biomass (1\%) (Figure 1). Solar energy has been included in the energy circuit since 2012 [7].

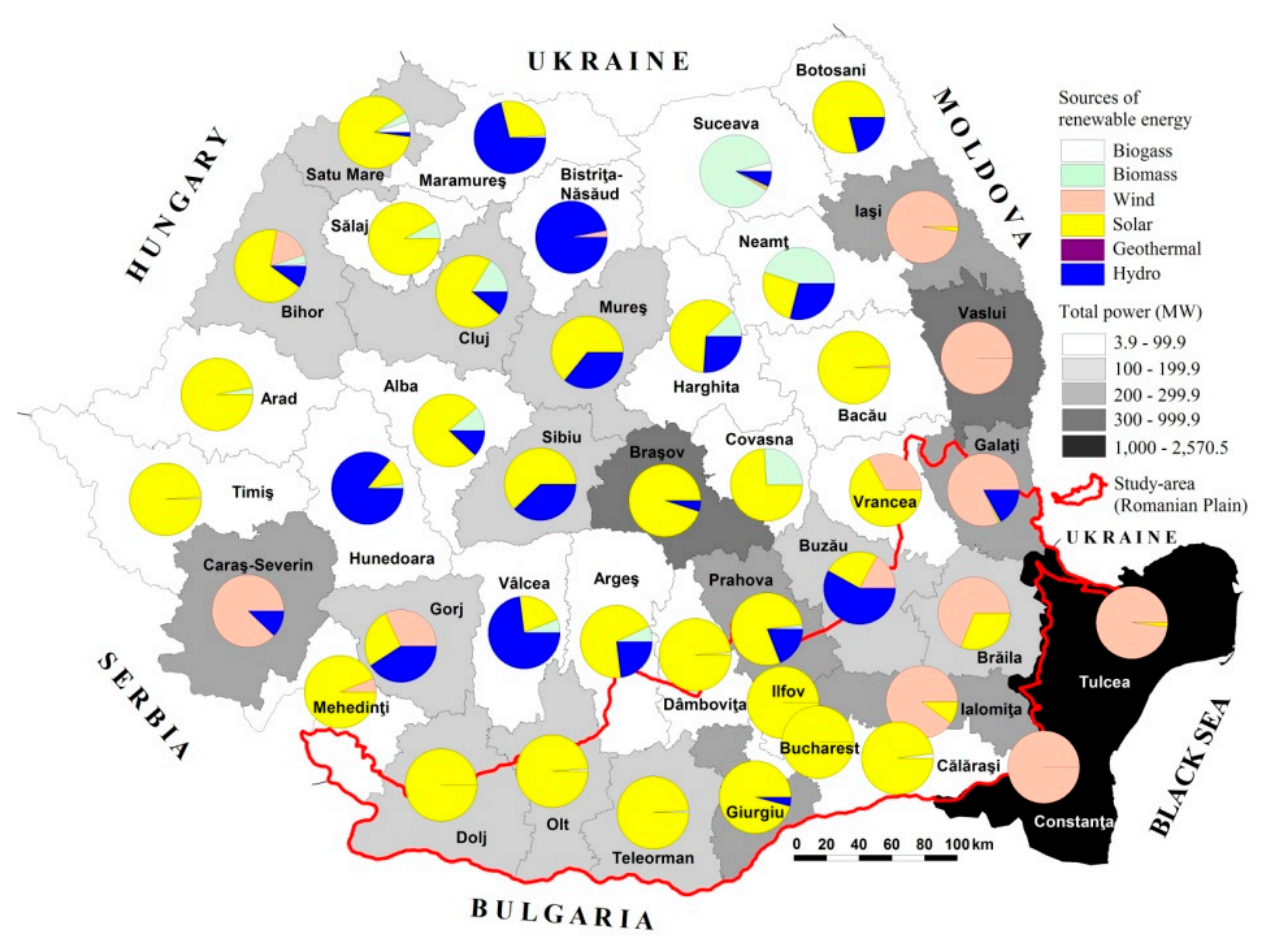

Figure 1. The use of renewable energy sources in Romania (2018) at the county level. (Source: data processed after [34]). (Note: for hydro power, only hydroelectric plants that appear after 2009 are listed). 


\section{Study Area}

The study area, the Romanian Plain, is located in the southern and south-eastern part of the country. Also known as the Lower Danube Plain (together with the Danube Floodplain), it is the largest plain area in Romania, stretching from west to east over $500 \mathrm{~km}$ along the Danube River [35,36]. This vast plain area spans over $52,600 \mathrm{~km}^{2}$ and covers $21 \%$ of the territory of Romania, being the second largest relief unit after the Carpathians (28\%) [36]. The Romanian Plain is the country's main agricultural region due to its specific natural conditions: lower altitudes of 10-200 m (locally $300 \mathrm{~m}$ ) and declivity, the existence of large areas covered with high fertility soils (e.g., chernisols and brown and reddish-brown argilluvic), relative homogeneity of morpho-hydrographic and climate features, and a high percentage of arable land $(80-90 \%$ of the total agricultural surface) [35]. The Romanian Plain is characterized by a temperate-continental climate, with submediterranean influences (more pronounced in the west) and aridity (more pronounced in the east) interposing a transition region where the two types of influence intermix [37]. In addition, the particular climatic characteristics in terms of high values of radiation and sunshine duration parameters turn the Romanian Plain into one of the regions with the greatest potential for developing solar energy projects. Thus, according to the Romanian Climatic Dataset (ROCADA) [38], the annual sunshine duration in the multiannual average regime in the Romanian Plain for the period 1961-2013 was between 6.0-6.4 h/day. As seen from Photovoltaic Geographic Information System (PVGIS) data, global irradiation of the solar potential for electric power by the optimal inclination of photovoltaic modules registers the highest values in the Romanian Plain (above $1500 \mathrm{kWh} / \mathrm{m}^{2}$ ). According to the same data source, global irradiance and solar potential for producing electricity through the use of photovoltaic modules in the horizontal position also record the highest values in the southern and south-eastern parts of the country (over $1300 \mathrm{kWh} / \mathrm{m}^{2}$ ), where the study area is located.

The plain regions in Romania are distinguished by a characteristic sunshine duration determined by the type of air mass circulation. In the Romanian Plain, the average annual sunshine duration sums over $2100 \mathrm{~h}$ in its eastern and south-eastern parts, exceeding $2200 \mathrm{~h}$ in its central and western parts, as a direct consequence of the prevalence of continental air [39]. For comparison, the highest annual sunshine duration in Romania (over $2300 \mathrm{~h}$ /year) is recorded on the Black Sea coast, a value resulting from the analysis of the distribution of the annual sums of the sunshine duration within the territory of Romania (Figure 2).

Throughout the year, the average number of sunshine hours shows great variability from one month to another, being closely related to the astronomical duration of the day and the nebulosity regime. The monthly average values of sunshine duration show that the highest average duration is recorded in July in the plain and hilly regions. Generally, the average sunshine duration in July exceeds $300 \mathrm{~h}$ in the Romanian Plain. On that account, the highest monthly values are recorded at Craiova meteorological stations ( $314.8 \mathrm{~h} /$ year). The territorial distribution of the average semesterly amounts shows that the warm semester of the year (April-September) is the main contributor to the annual sunshine duration, with about $70 \%$ of the annual value in the hilly and plain regions. Overall, the highest number of sunshine hours in the warm semester (over $1600 \mathrm{~h}$ ) is registered on the Black Sea coast, in the Danube Delta, and in the eastern parts of the Romanian Plain [39]. The distribution of annual average fluxes of direct solar radiation at the latitude of Romania highlights the concentration of the most important solar energy potential exploitable in the plain areas. According to the National Research and Development Institute for Energy (ICEMENERG), the solar energy potential of the study area falls in Zone I of exploitation, holding a possible $1350 \mathrm{kWh} / \mathrm{m}^{2}$ per year.

The spatial distribution of solar energy systems is driven by suitability factors (biophysical and socio-economic), which explains the geographical potential to set up PV farms. These factors may range from solar radiation, orientation, and slope to urban areas, land use/cover, population, transport networks, and electricity grids [11]. 


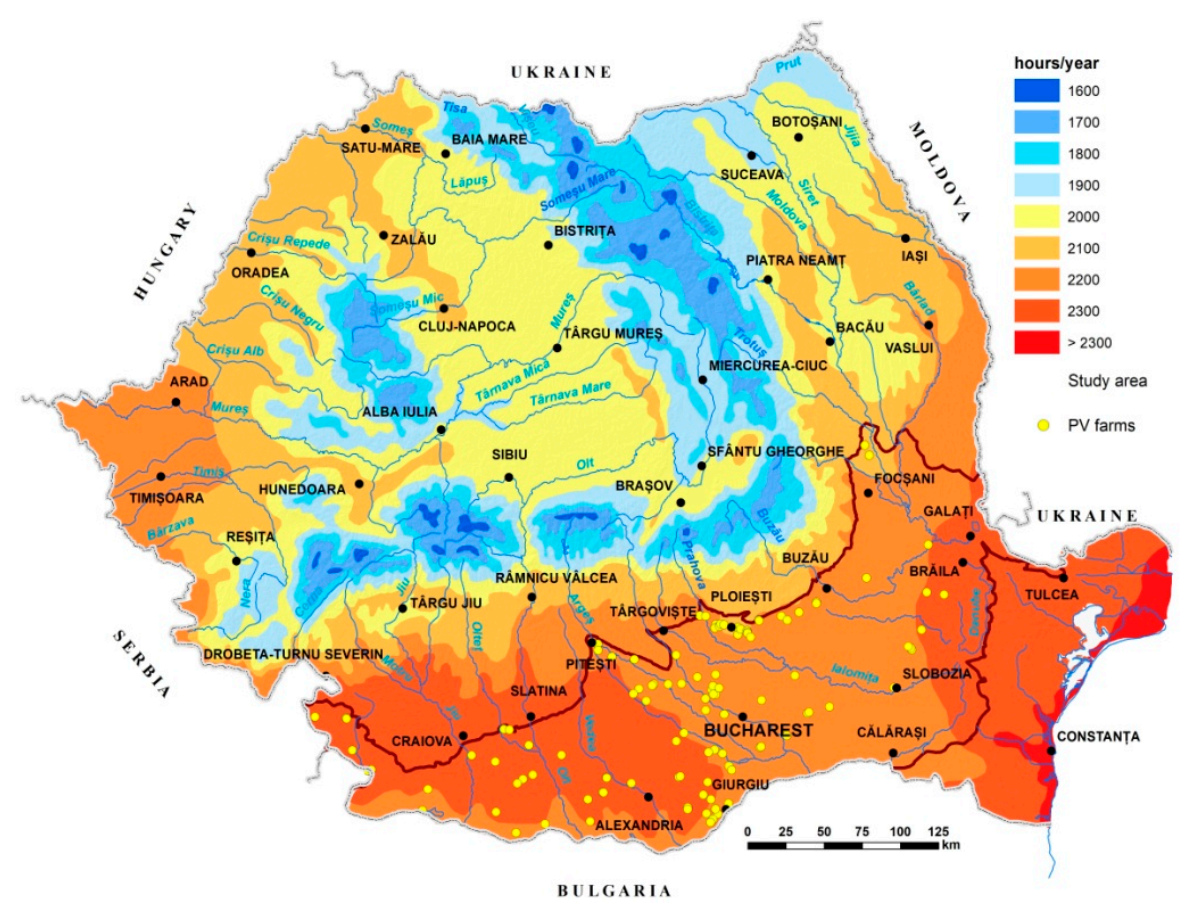

Figure 2. Annual sunshine duration in Romania [39] and the spatial distribution of photovoltaic (PV) farms in the study area (authors' processing).

\section{Materials and Methods}

Before analyzing the spatial distribution of PV farms, the characteristics and environmental impacts of solar energy resources in Romania have been evaluated based on data available from National Meteorological Administration [32,39], ROCADA v1.0 [38], PVGIS, [40] and ICEMENERG data [41].

The location of PV farms was visually extracted from satellite images (Landsat 7 ETM and Landsat 8 OLI, 2018) for the entire Romanian Plain. The resulting spatial data were correlated and completed with records provided by the Romanian Transmission and System Operator (TSO) Transelectrica (e.g., the installed power and type of each PV farm). Finally, in order to highlight the impacts of PV farms on the environment, several statistical and spatial indicators were performed, namely, the share/surface of PV farms at county the level, the share of PV farms of each land use/cover category (based on CORINE Land Cover 2012), the distance to forests, water, Natura 2000 protected areas, and the share of PV farms of main soil types. Based on the resulting statistics, the authors were able to identify the existing and potential environmental impacts of solar systems on specific environmental components.

\section{Results}

\subsection{The Identification of PV Farms in the Romanian Plain}

In the Romanian Plain there are 110 PV farms which were built between 2010 and 2017 (mainly in 2013 (68) and 2014 (27)), of areas ranging between 0.25 ha (in Prahova County) and 142 ha (in Giurgiu County), which are unevenly distributed across the relief units and at the county level. The largest number of farms are located in the Giurgiu (20), Prahova (19), Dâmbovița (15), and Brăila (11) counties. With regard to large relief units, the Teleorman and Ialomița Plains hold almost $60 \%$ of solar systems (Figures 3 and 4). The prevalence of PV farms in the central part of the Romanian Plain is related to land availability and suitability (e.g., abandonment and low land prices), but also financial support (e.g., subsidies and the influence of the legislative context). 


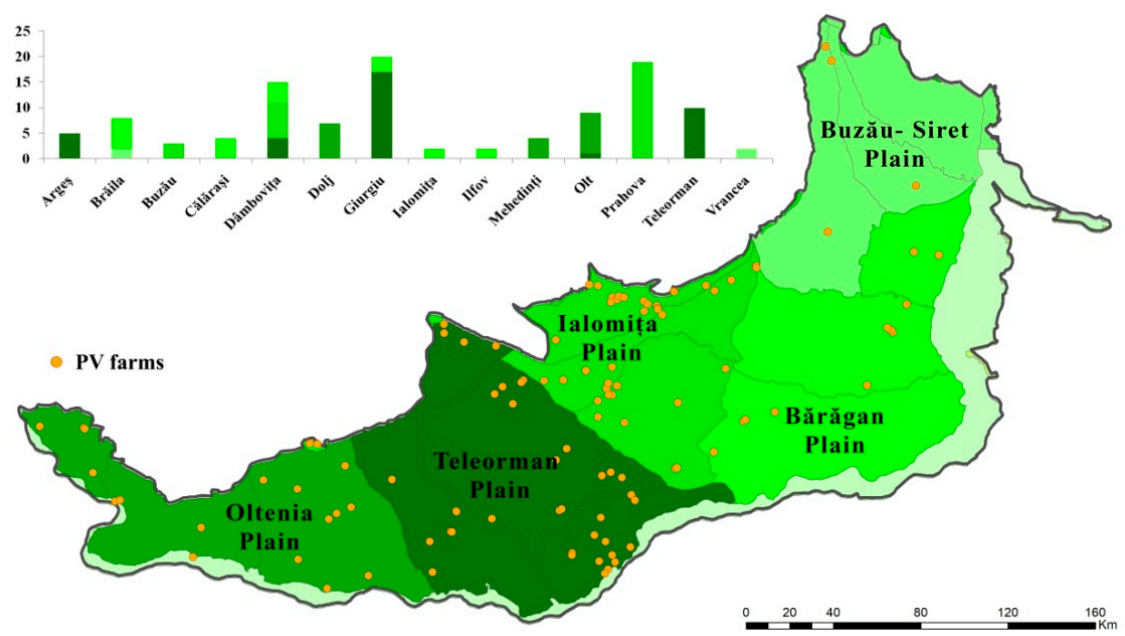

Figure 3. Spatial distribution of PV farms on relief units.

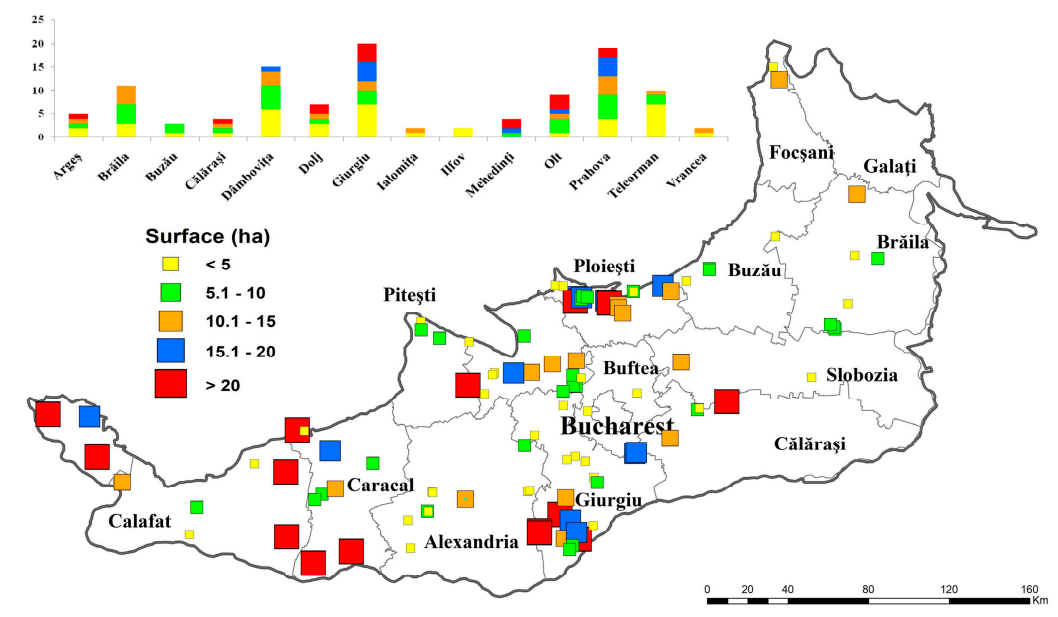

Figure 4. Surface and spatial distribution of PV farms at the county level.

The installed power of PV farms is generally low and nearly $30 \%$ of the installations produce less than $3 \mathrm{MW}$, of which $17 \%$ produce below $1 \mathrm{MW}$. Larger systems (producing over $9 \mathrm{MW}$ ) cover only about $13 \%$ of the territory, with most of these located in the Prahova, Giurgiu, and Dolj counties (Figure 5).

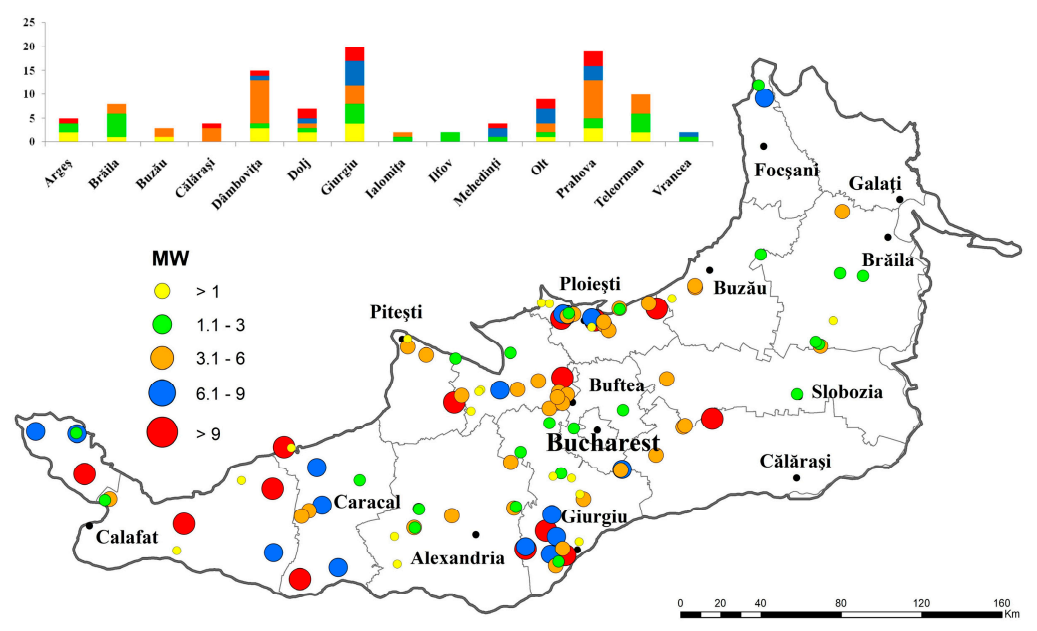

Figure 5. The installed power of PV farms. 


\subsection{The Main Environmental Impacts of PV Farms}

Solar energy systems are known as the least polluting energy source, providing significant environmental benefits in comparison to conventional energy sources [9]. However, solar energy systems might also have direct or indirect negative implications for land use/cover and landscape, ecosystems, climate change, and human health and safety, etc. (Table 1). Generally, the impacts of PV farms on landscape and the environment might occur at different rates and magnitudes throughout their duration (i.e., in relation to construction, operation, and decommission) [2], but start from the early stages of construction, driven by building activities [9]. Manufacturing PV modules can also have consequences for workers and on the environment throughout their life cycle (from raw material extraction and procurement, to manufacturing, disposal, and/or recycling) [10].

Table 1. Environmental impacts of photovoltaic farms.

\begin{tabular}{|c|c|c|}
\hline $\begin{array}{l}\text { Categories of } \\
\text { Impacts }\end{array}$ & Positive & Negative \\
\hline $\begin{array}{l}\text { Land Use and } \\
\text { Landscape }\end{array}$ & $\begin{array}{ll}- & \text { use/reuse of degraded/unused sites } \\
\text { - } & \text { less use of land compared to } \\
\text { conventional energy resources }\end{array}$ & $\begin{array}{l}\text { - competition with other land use categories } \\
\text { (i.e., agricultural) }\end{array}$ \\
\hline Ecosystems & N/A & $\begin{array}{ll}- & \text { degradation of vegetation } \\
- & \text { soil erosion } \\
- & \text { invasive plant species } \\
- & \text { habitat loss and fragmentation } \\
- & \text { biodiversity loss (especially birds through } \\
\text { - } & \text { collision-related and flux-related mortality) } \\
\text { attraction and disorientation of insects and } \\
\text { birds caused by bright and/ or polarized light }\end{array}$ \\
\hline $\begin{array}{l}\text { Environmental } \\
\text { Quality }\end{array}$ & $\begin{array}{ll}\text { - } & \text { reduction of greenhouse gases } \\
\text { emissions (mainly } \mathrm{CO}_{2}, \mathrm{NO}_{\mathrm{x}} \text { ) } \\
\text { - } \quad \text { improvement of water } \\
\text { resources quality }\end{array}$ & 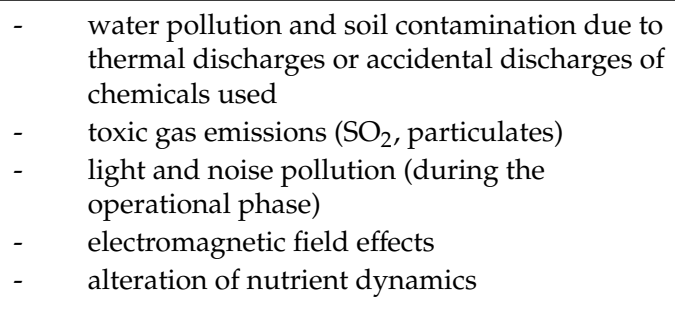 \\
\hline $\begin{array}{l}\text { Climate } \\
\text { Change }\end{array}$ & $\begin{array}{l}\text { reduction of greenhouse } \\
\text { gas emissions }\end{array}$ & $\begin{array}{ll}- & \text { microclimatic change } \\
- & \text { changes in albedo } \\
\text { - } & \text { thermal pollution }\end{array}$ \\
\hline $\begin{array}{l}\text { Human health } \\
\text { and Safety }\end{array}$ & N/A & air pollution \\
\hline $\begin{array}{l}\text { Supporting } \\
\text { Infrastructure }\end{array}$ & $\begin{array}{ll}- & \text { reduced transmission lines/grids } \\
\text { - } & \text { acceleration of decentralized } \\
& \text { rural electrification }\end{array}$ & $\begin{array}{ll} & \text { requirements for energy storage for } \\
\text { continuous supply } \\
\text { - } & \text { ecological impacts (e.g., habitat fragmentation) }\end{array}$ \\
\hline $\begin{array}{c}\text { Public } \\
\text { Awareness }\end{array}$ & $\begin{array}{ll}- & \text { increased } \\
\text { environmental consciousness } \\
\text { - } & \text { increased public image }\end{array}$ & N/A \\
\hline
\end{tabular}

Based on $[2,9,10,14,15,18,42,43]$ adapted and completed by the authors.

The impact of PV farms on land use/cover depends on several factors such as topography, the surface area covered by the PV farms, or the type of land use. It might refer to both land transformation (land use change) and land occupation (land use for a certain period) $[16,17]$. On the one hand, agricultural land, in particular, is increasingly being used to site solar installations (e.g., large- and utility-scale solar projects), followed by shrubland, pasture/hay, and grass/herbaceous land $[13,44]$. On the other hand, the use of marginal lands to locate PV systems might avoid the uptake of agricultural land [11]. In the study area, the largest number of PV farms (79\%) is located on non-irrigated arable land, followed by pastures, complex cultivation patterns, discontinuous urban 
fabric and industrial and commercial units (e.g., former agricultural farms or silos), and vineyards. In terms of share, the largest share of PV farms is found in four counties (Giurgiu, Prahova, Dâmbovița, and Olt) (Figure 6).
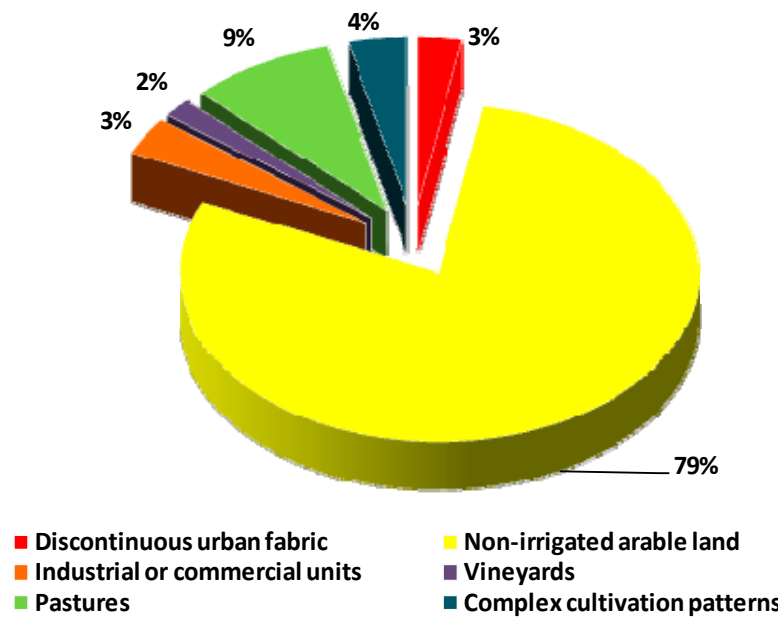

(a)

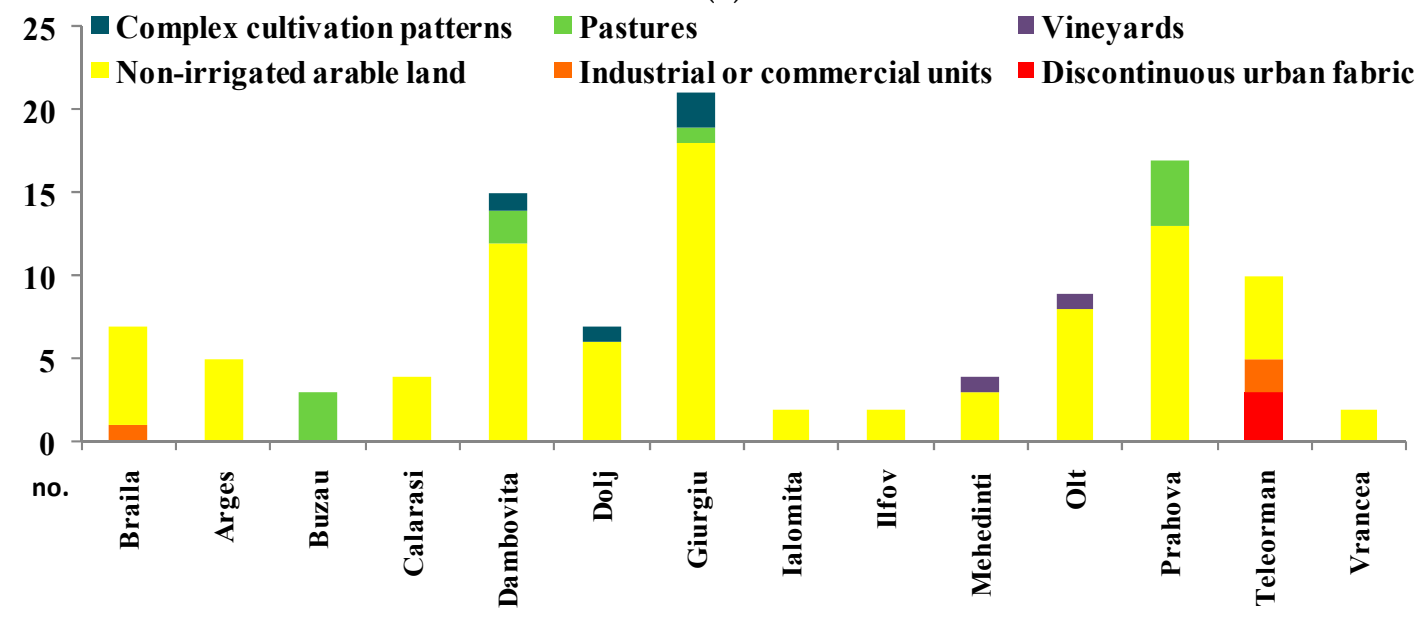

(b)

Figure 6. PV farm distribution for land use/cover categories in the Romanian Plain (a) and at the county level (b).

The application of PV farms within agricultural land (mainly arable) most probably will affect soil quality and productivity [9]. The impacts on landscape (e.g., visual and noise pollution) are generally reduced. Solar energy is a static source which does not suffer from noise problems, while visual intrusion is highly dependent on the type and surroundings of the PV systems (i.e., in proximity to an area of natural beauty, the visual impact would be significantly high [16]), as well as on the size or location [12]. Landscape fragmentation is expected, in turn, to impact biodiversity by creating barriers to the movement of species and their genes [2].

The impacts of solar energy systems on ecosystems mainly refer to habitat changes or loss, given that the development of solar energy infrastructure can take up significant amounts of land, modifying and fragmenting habitats in the process of implementation [18] or in relation to the proximity of PV farms to sensitive or valuable ecosystems (e.g., forests and protected areas). In the study area, almost $45 \%$ of PV farms are located less than $2 \mathrm{~km}$ from forests, especially in the Prahova, Giurgiu, and Dâmbovița counties, underlying the potential of forest ecosystems to be affected by the solar systems in the process of installation, but also during maintenance and repairing services. Despite this, 
nearly $32 \%$ of PV farms are located at greater distances from forests (over $4 \mathrm{~km}$ ), hence diminishing the possibility of the forests being disturbed by related environmental consequences (Figure 7).

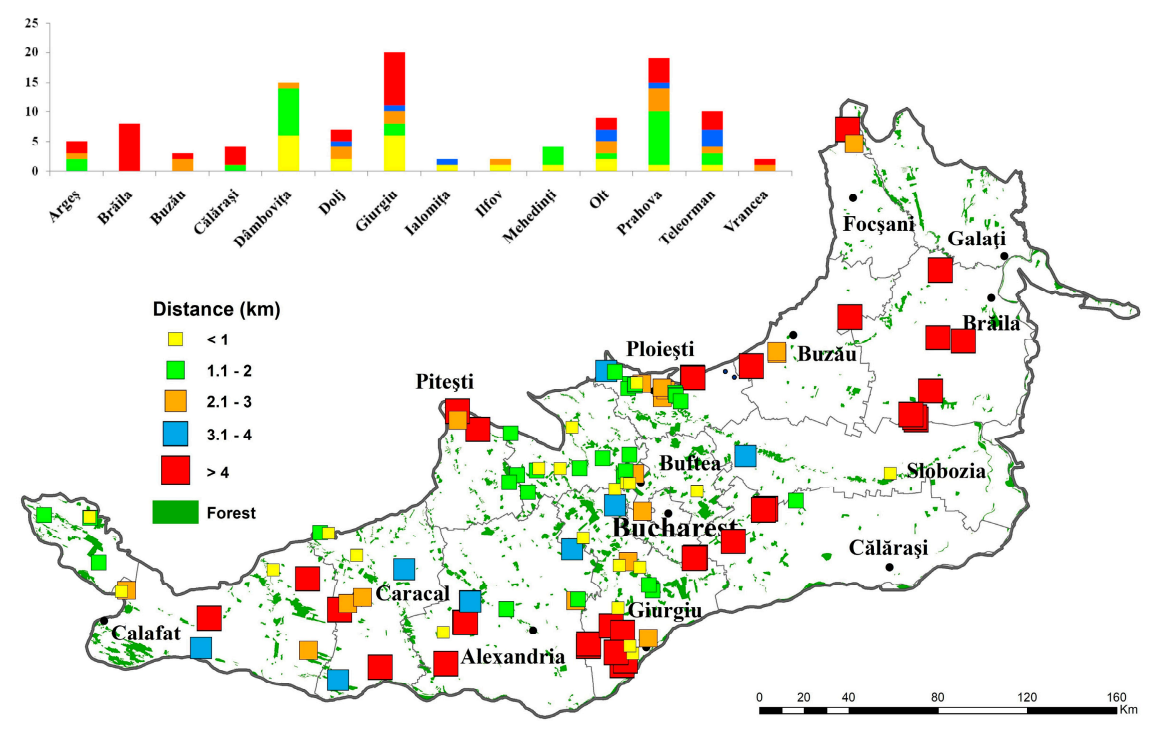

Figure 7. Distance of PV farms to forests.

The proximity of PV farms to Natura 2000 protected areas, Sites of Community Importance (SCI) and Special Protected Areas (SPA), can have significant impacts on habitats and biodiversity generally driven by the PV farm footprint (i.e., areas which are directly transformed or impacted by the PV installation), where the vegetation is cleared and soils typically degraded $[2,18]$.

In the study area, there are some PV farms located inside protected areas which enhance the potential of affecting habitats and species: two PV farms inside Comana SCI and SPA (Giurgiu County) and 1 PV inside SPA Blahnița (Mehedinți County). In spite of this, in the case of SPAs, most PV farms are located at greater distances (over $10 \mathrm{~km}$ ) compared to SCIs, to which $29 \%$ of PV farms are located at $0.1-5 \mathrm{~km}$ and $30 \%$ at $5.1-10 \mathrm{~km}$ distance (Figures 8 and 9 ). Bird species, in particular, are directly affected by PV systems through two types of direct solar energy-related bird mortality: collision-related mortality (direct collision with heliostats) and solar flux-related mortality (burning from exposure to concentrated sunlight) [14,15].

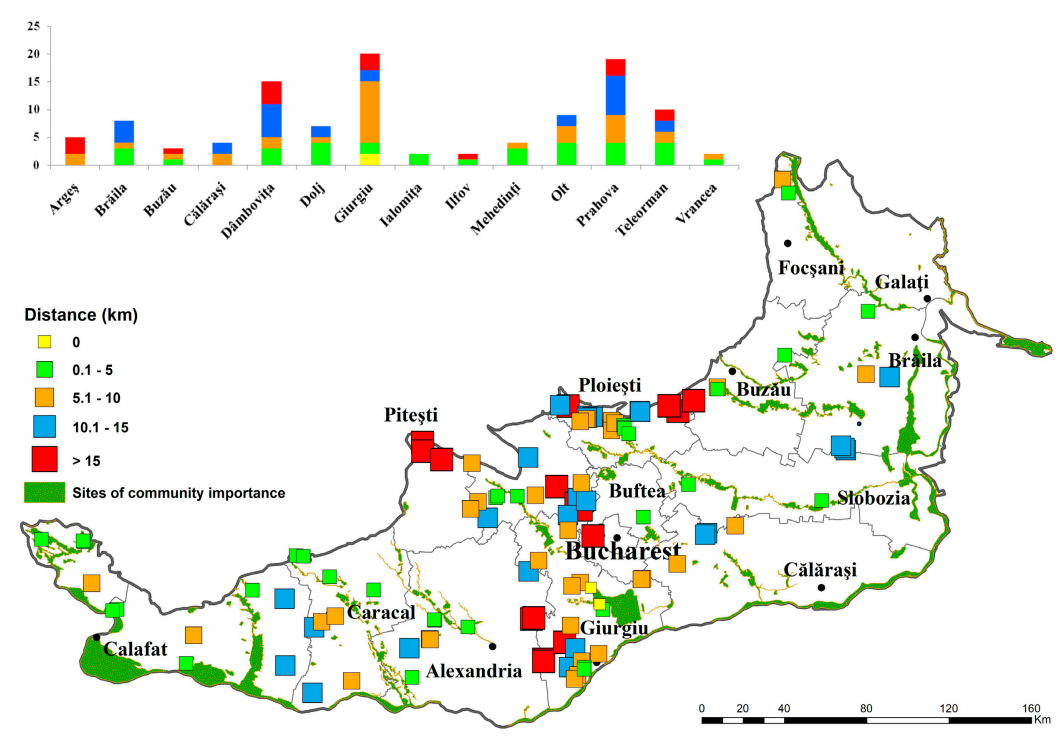

Figure 8. Distance of PV farms to SCIs. 


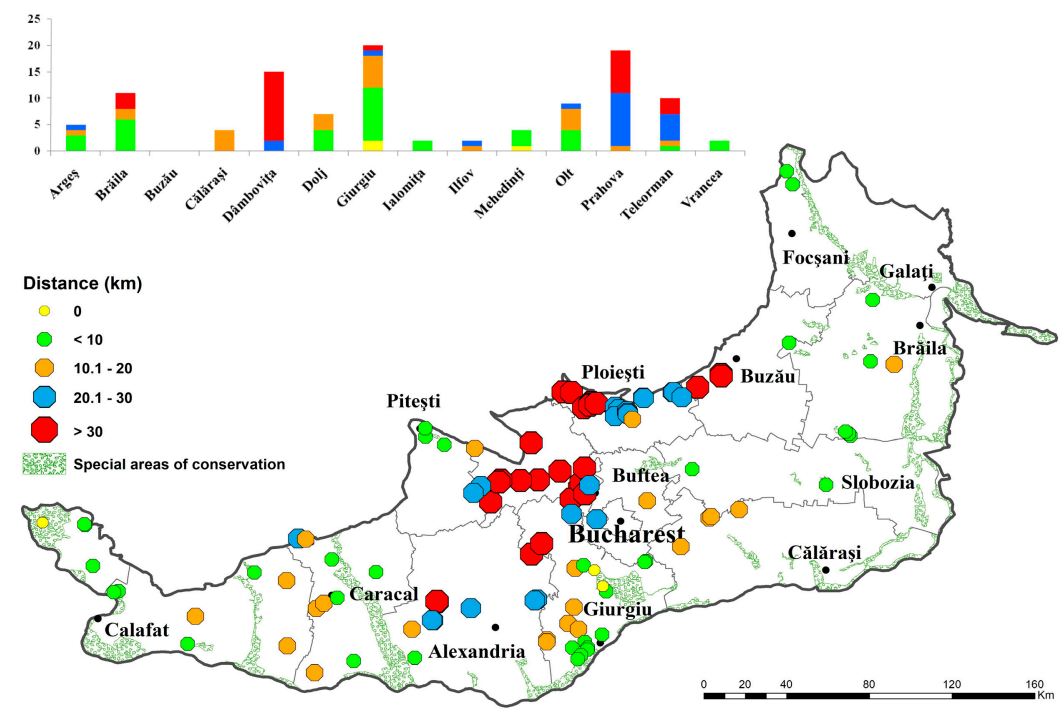

Figure 9. Distance of PV farms to SPAs.

The effects of PV farms on environmental quality are generally related to water, soil, or air. No air pollution during power generation is one of the main advantages of solar energy, making solar energy among the cleanest forms of energy on earth. Nonetheless, some toxic materials are used in solar cell manufacturing [16]. The removal of vegetation from areas where the PV farms are installed exposes soil to different processes (e.g., degradation, compaction, and grading), which, in time, can lead to land degradation and land productivity loss, especially when dealing with high-quality soils. Moreover, solar parks may alter the carbon cycle through changes in soil temperature, precipitation, and evapotranspiration (soil moisture) [45].

In the Romanian Plain, which is known for its valuable soil resources for agriculture, the impact of PV farms is even greater. Most PV farms are located on fertile soils (52\% of the total): haplic chernozems (24, mostly in the Teleorman, Călărași, and Giurgiu counties), reddish-brown soils (22, predominantly in the Dâmbovița, Giurgiu, Ilfov, and Dolj counties) and chernozems (11, mainly in the Brăila, Giurgiu, and Dolj counties). Only 12\% of PV farms are located on degraded or unproductive soils (e.g., erodisols, pelisols, and solonetz) largely located in the Dâmbovița and Giurgiu counties (Figure 10). Nonetheless, the latter indicates the increased potential of solar energy installations of reclaiming degraded or abandoned sites and giving them economic value.

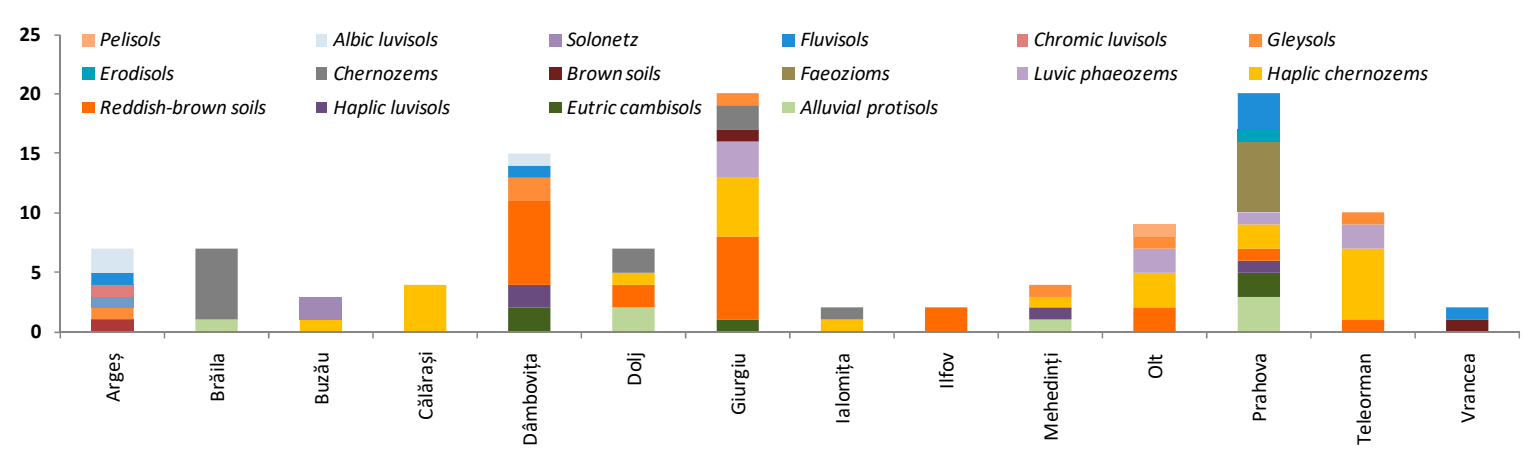

Figure 10. PV farm distribution in relation to main soil types and counties.

Depending on the soil texture, silt and clay particles can be easily removed and transported by water or wind, thus accelerating soil degradation, but also leading to a broad spectrum of impacts ranging from impacts on human health, impacts on biogeochemical or hydrologic cycles, and even desertification [2]. 
The relationship between PV farms and water use and quality can be accounted for using a two-sided perspective. On the one hand, the impact of the farms is related to water extraction, in terms of the quantity used to clean PV installations, which is not returned into the source [2]. On the other hand, the use of chemical substances in the process of washing the panels leads to the infiltration of contaminated waters into the soil and later into the phreatic layer, as well as into nearby rivers. As a consequence, the proximity of water sources is an important indicator since this shows the possibility of the hydrological system being contaminated by thermal discharges or accidental discharges of chemicals used. The largest share of PV farms ( $40 \%$ within less than $1 \mathrm{~km}$ and $28 \%$ between 1 and $2 \mathrm{~km}$ ) are located very close to water bodies, especially in the Prahova, Dâmbovița, and Giurgiu counties (Figure 11). This pinpoints the high exposure of water bodies to being overexploited or polluted.

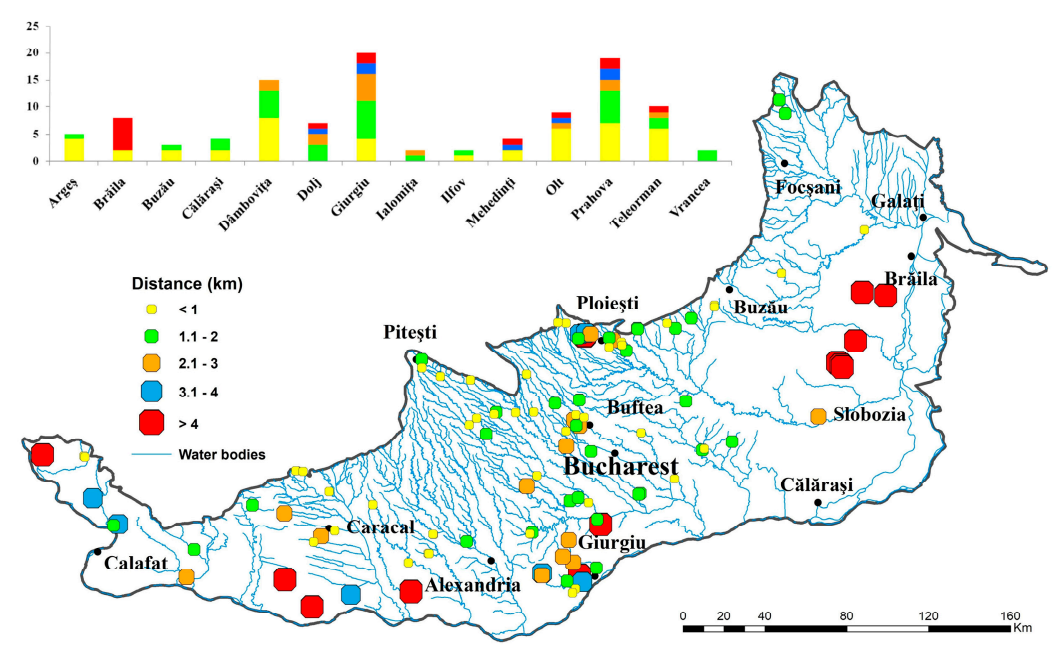

Figure 11. Distance of PV farms to water bodies.

With regard to climate change-related effects, PV farms have a major positive impact in terms of reducing greenhouse gas emissions [1] and enhancing resource efficiency (two key pillars of the United Nations Environmental Programme (UNEP) Green Economy Report) [18]. Nevertheless, at local scales they can produce changes in albedo and evapotranspiration, therefore having important climatic effects $[1,18]$. Because of their distribution in a region with high solar resources, PV farms located in the study area are likely to have an increased impact on the surrounding space, especially forest ecosystems and protected areas, through increasing local temperature and evapotranspiration.

The effects of PV farms on human health and safety are generally related to air quality, i.e., airborne dust particles or toxic compounds (e.g., ammonia, arsenic, and nitric acid) and their impacts on the health of employees in different stages of installation, use, and maintenance [16]. In the study area, the location of most of the PV farms close to water bodies ( $40 \%$ within less than $1 \mathrm{~km}$ and $28 \%$ between 1 and $2 \mathrm{~km}$ ) with potential impacts on water quality may also impact human health and safety through the use of polluted water in households or agriculture.

The supporting infrastructure has a series of positive impacts in terms of reduced transmission lines/grids compared to conventional energy sources, as well as the acceleration of rural electrification [2,9]. Yet, the spatial distribution of transmission lines and corridors may also have negative ecological impacts related to habitat fragmentation (especially forests), displacement of wildlife, and vegetation cover removal [2]. In addition, the proximity to settlements (Figure 12) can be a positive aspect, as the shorter the distance to localities, the more reduced the impact on the environment through diminishing the effects of materials or substances transported during installation or maintenance works. Almost $60 \%$ of the PV farms are located within a distance of less than $1 \mathrm{~km}$ from the settlements, especially in the Prahova, Dâmbovița, and Brăila counties. 


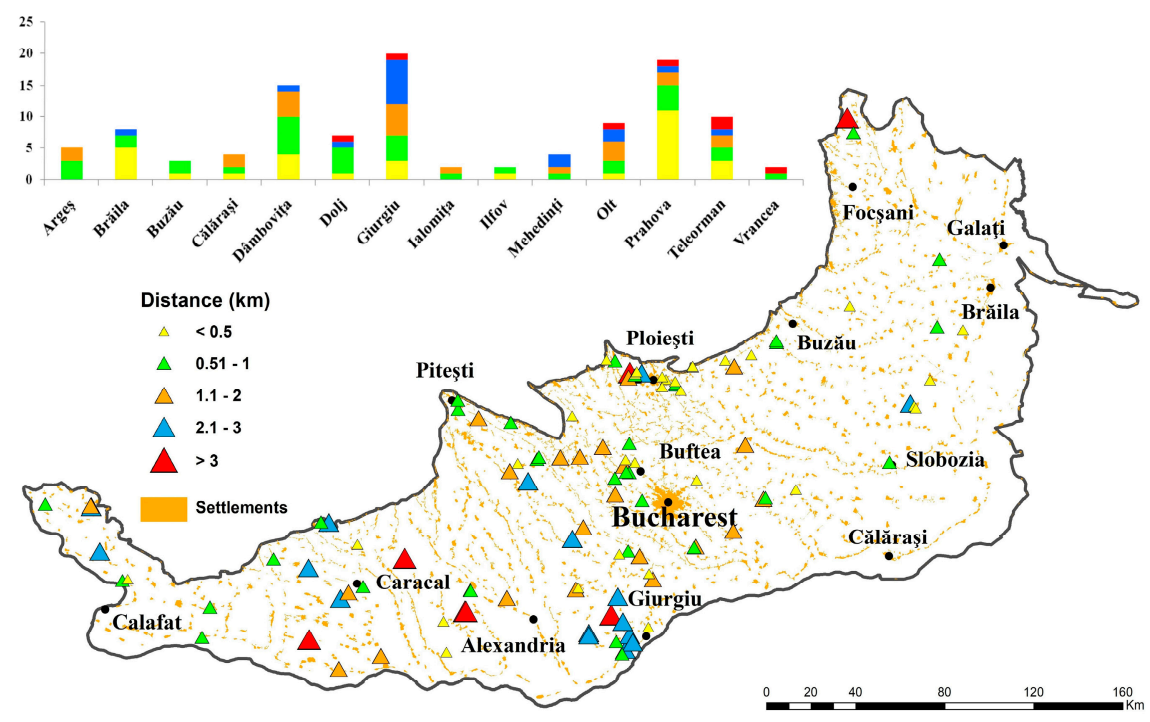

Figure 12. Distance of PV farms to settlements.

Proximity to roads is important since this enables access to PV farms, but this might also contribute to the potential fragmentation of habitats or ecosystems through access of materials or substances necessary for solar installations within different ecosystems, increasing their related impacts. Almost $44 \%$ of PV farms are located close to national roads, particularly in the Prahova, Dâmbovița, Brăila, and Giurgiu counties (Figure 13).

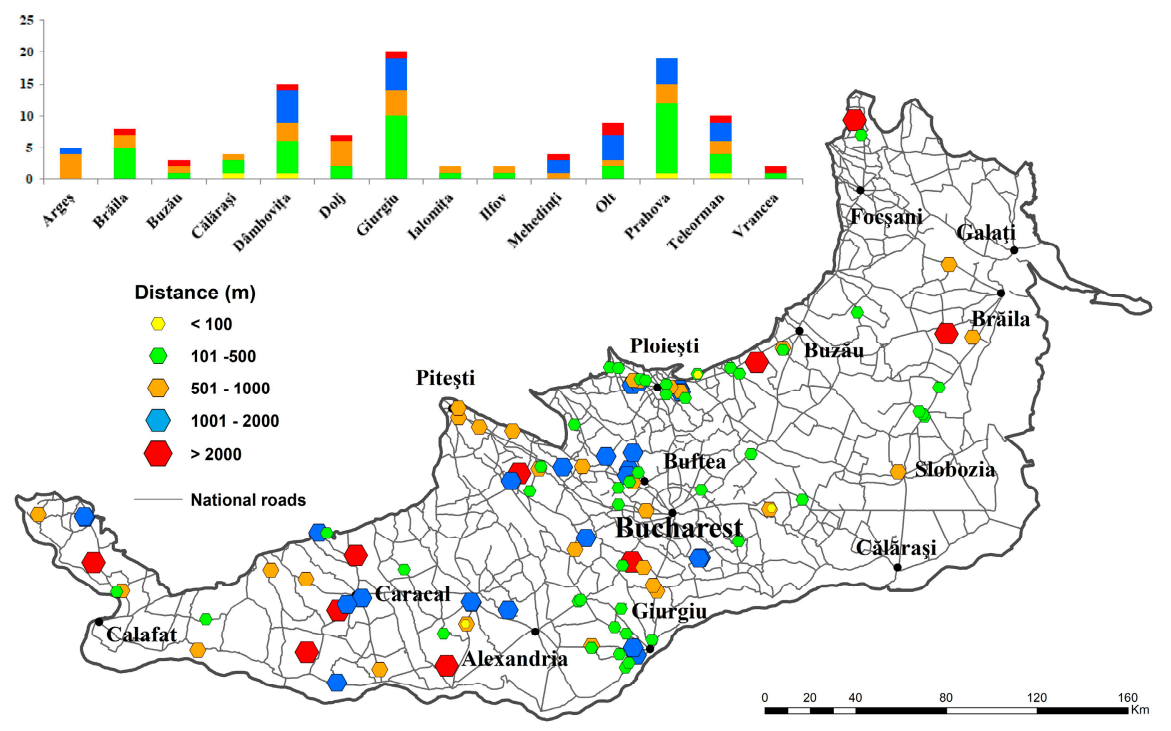

Figure 13. Distance of PV farms to national roads.

\subsection{The Impacts of PV Farms on the Local Environment-Evidence from the Giurgiu Rural Area}

Giurgiu County's demographic potential over the past decade has fallen by $9 \%$ and at the beginning of the current decade the population is aging ( $20 \%$ are over-68-year-olds out of the total population) and becoming more economically dependent (e.g., the economic dependency rate is quite high, being $136 \%$ ) as a consequence of the high inactivity rate (55.06\%). Agriculture (both subsistence and intensive) represents a very important economic activity, with all of the county's economy and labor force depending on it. In 2011, employment in this sector was $43.6 \%$, with countryside values of up to $80-85 \%$. In terms of social-economic development, the three case studies lie in a very low socio-economic development rural area $[46,47]$. 
According to data provided by the Transelectrica Company, in Giurgiu County 25 photovoltaic energy producers are operating in 19 communes and in the Giurgiu Municipality [26]. Of these, two photovoltaic farms were studied by us in terms of their impacts on the environment: SC Long Bridge Milenium SRL Stăneşti and SC Borra Energy Plant SRL Izvoarele. Detailed aspects related to impacts on the environment were to be revealed by field investigation and discussions with local investors and local authorities. Additionally, some documents published by the Giurgiu County for Environmental Protection were utilized (e.g., [48,49])

The SC Long Bridge Milenium SRL is located in the northern part of the locality, with an area of $174,972 \mathrm{~m}^{2}$ (out of town on arable land), at a distance of $0.5 \mathrm{~km}$ from County Road 503, in the northern part of the Giurgiu-Videle railway line, $1.5 \mathrm{~km}$ away from the power station at Ghizdaru and $2.5 \mathrm{~km}$ away from the residential area. The process of producing electricity through the conversion of solar energy by means of photovoltaic panels does not generate waste directly, and the changing of pieces presupposes the handing over of those already used by a specialized collection company. After the life of photovoltaic panels has expired, they will be dismantled, with most of the components being reusable (aluminum and glass will be recycled and the rubber in the gaskets is taken to a company specializing in its recovery/disposal) (source: field investigation).

The SC Borra Energy Plant SRL Izvoarele occupies 761,574 $\mathrm{m}^{2}$ and is located on the southern outskirts of the administrative-territorial unit, also on arable land. The solar park, located near County Road 503 and the Giurgiu-Videle railway line, consists of three distinct parts: Zone 1, with an area of $450,074 \mathrm{~m}^{2}$, covered with 101,088 solar panels; Zone 2, with an area of 286,600 $\mathrm{m}^{2}$, with 59,952 solar panels; and Zone 3, with an area of $24,900 \mathrm{~m}^{2}$, covered with only 3384 solar panels.

In both cases, the PV farms' operation implies the existence and potential impacts on local biodiversity of dust suppressants, rust inhibitors, antifreeze agents, and herbicides. Also, for the setting-up of both photovoltaic farms, changes in vegetation (which involves removal and especially grass reduction) were required, being strongly linked to increases in dust production, land grading, soil compaction, and construction of access roads (this activity increases soil loss by wind and water). Water is used only for panel washing and dust suppression in places, with dust deposition being a potential issue in terms of water, soil, and air pollution.

It is worth mentioning that in the case of damage to some of the solar panels, the time for replacement and handing over the damaged panels to the specialized company should be as short as possible in order to minimize the risk of exposure to the various toxic materials from which the panels are made (e.g., inhalation of silicon particles may occur).

\section{Conclusions}

Among the key objectives of the Energy Strategy of Romania 2016-2030 are the provision of technical and economic measures that will lead to energy efficiency and the removal of the polluting impact of energy production and consumption via the promotion of the use of renewable energy resources [50]. Solar energy is by far one of the most appropriate and promising renewable resource and technology alternatives to fossil fuels, and is especially used to mitigate climate change [2]. For this reason, increasing the share of solar energy has been a main achievement in terms of reaching energy efficiency goals both in the EU and at the national level.

Under the constant growth of solar energy producers at the national level (from one producer in 2009 to 576 producers in 2016), solar power has become an important part of the national renewable energy system, with generally positive effects on the local economy. On the other hand, there are a number of shortcomings, such as the insufficient functional integration of large solar energy projects into local communities, with no real and sustained positive impact on rural development and the negative implications of installing a solar park on farmland [38]. However, although it provides clean and sustainable energy, Romania's solar energy potential is still underexploited. At the national level, the Romanian Plain has among the highest exploitable energy potential where the intensity of solar radiation can exceed $1350 \mathrm{kWh} / \mathrm{m}^{2} /$ year. In this context, several measures might be taken for a more 
efficient exploitation of the solar potential in the study area and to support sustainable development in rural areas: the development of PV farms in terms of adaptation to worldwide trends (e.g., PV farms with pastures thriving under solar panels), and the endowment of buildings with photovoltaic equipment, etc. Thus, it is important to protect and preserve valuable farm land and other local environmental resources by adopting some solutions such as smaller systems for individual or clusters of households and small rural communities.

The solar energy industry, as part of the Romanian renewable energy industry, is influenced at all territorial levels by natural, legislative, and economic factors. At the national level, a diversification of renewable energy sources and diversification of electricity production (since 2012), followed by an increase in the number of solar energy producers (between 2009 and 2016) has been noticed, while at the regional level (in the Romanian Plain region in particular), due to favorable biophysical factors, solar energy resources have been better and intensively exploited and used. In-depth studies at the local level have revealed that large solar energy projects located in the south and central part of Romania are not functionally integrated into local communities with no sustainable impact on rural development and that local community leaders are unaware of the negative implications of installing a solar park on farmland [26,30]. Within the study area, PV farms are mainly concentrated in the Prahova, Dâmboviţa, and Giurgiu counties, overlapping non-irrigated arable land (79\%), but also on pastures, complex cultivation patterns, discontinuous urban fabric, and industrial and commercial units. Although they provide a clean and sustainable energy source, solar energy systems also could entail negative environmental implications, generally impacting land use and landscape, ecosystems, climate change, and human health and safety. Rural communities could be the main beneficiaries of the development of renewable resources in order to promote sustainable development.

The use of solar renewable sources comes as a response to Romania's concern regarding its transition to a green economy, adapting to climate change, and diminishing the negative effects of human activity on the environment, as set out in strategic documents such as the National Strategy for Sustainable Development of Romania-Horizons 2013-2020-2030 and the National Climate Change Strategy (2013-2020). At the same time, it could mainstream the development of sustainable employment and infrastructure opportunities (e.g., green jobs and green and innovative technologies) through progress in research and development, greening industries, education, and up-skilling for green jobs, etc.

Author Contributions: All authors have made equal contributions to the preparation of this scientific paper.

Funding: This work was supported by the project PN-III-P1-1.2-PCCDI-2017-0404/31PCCDI/2018 (UEFISCDI) - Holistics of the Renewable Energy Sources on Environment and Climate (HORESEC).

Conflicts of Interest: The authors declare no conflict of interest.

\section{References}

1. Dale, V.H.; Efroymson, R.A.; Kline, K.L. The land use-climate change-energy nexus. Landsc. Ecol. 2011, 26, 755-773. [CrossRef]

2. Hernandez, R.R.; Easter, S.B.; Murphy-Mariscal, M.L.; Maestre, F.T.; Tavassoli, M.; Allen, E.B.; Barrows, C.W.; Belnap, J.; Ochoa-Hueso, R.; Ravi, S.; et al. Environmental impacts of utility-scale solar energy. Renew. Sustain. Energy Rev. 2014, 29, 766-779. [CrossRef]

3. EC. Europe 2020: A Strategy for Smart, Sustainable and Inclusive Growth European Commission; European Commission: Brussels, Belgium, 2010. Available online: http://eur-lex.europa.eu/LexUriServ/LexUriServ.do? uri=COM:2010:2020:FIN:EN:PDF (accessed on 15 July 2018).

4. UN. United Nations Decade of Sustainable Energy for all 2014-2024. Available online: https://www.un.org/ press/en/2012/ga11333.doc.htm2014 (accessed on 19 July 2018).

5. Scarlat, N.; Dallemand, J.F.; Monforti-Ferrario, F.; Banja, M.; Motola, V. Renewable energy policy framework and bioenergy contribution in the European Union-An overview from National Renewable Energy Action Plans and Progress Reports. Renew. Sustain. Energy Rev. 2015, 51, 969-985. [CrossRef] 
6. Radovanović, M.; Filipović, S.; Pavlović, D. Energy security measurement-A sustainable approach. Renew. Sustain. Energy Rev. 2017, 68, 1020-1032.

7. Grigorescu, I.; Micu, D.; Dumitrașcu, M.; Mitrică, B.; Mocanu, I.; Șerban, P.; Dumitrică, C.; Havriș, L.; Kucsicsa, G. Renewable Energy Resources in Romania. Progress and Perspectives Towards the EU Targets. In Proceedings of the Air and Water-Components of the Environment, Cluj-Napoca, Romania, 22-24 March 2019; pp. 9-18. [CrossRef]

8. EUROBSERV'ER. Photovoltaic Barometer. 2018, pp. 1-16. Available online: https://www.eurobserv-er.org/ photovoltaic-barometer-2018/ (accessed on 17 January 2019).

9. Tsoutsos, T.; Frantzeskaki, N.; Gekas, V. Environmental impacts from the solar energy technologies. Energy Policy 2005, 33, 289-296. [CrossRef]

10. Dubey, S.; Jadhav, N.Y.; Zakirova, B. Socio-economic and environmental impacts of silicon based photovoltaic (PV) technologies. Energy Procedia 2013, 33, 322-334. [CrossRef]

11. Castillo, C.P.; E Silva, F.B.; Lavalle, C. An assessment of the regional potential for solar power generation in EU-28. Energy Policy 2016, 88, 86-99. [CrossRef]

12. Bergmann, A.; Colombo, S.; Hanley, N. Rural versus urban preferences for renewable energy developments. Ecol. Econ. 2008, 65, 616-625. [CrossRef]

13. Hernandez, R.R.; Hoffacker, M.K.; Murphy-Mariscal, M.L.; Wu, G.C.; Allen, M.F. Solar energy development impacts on land cover change and protected areas. Proc. Natl. Acad. Sci. USA 2015, 112, 13579-13584. [CrossRef]

14. Ho, C.K. Review of Avian Mortality Studies at Concentrating Solar Power Plants. In AIP Conference Proceedings; AIP Publishing: Melville, NY, USA, 2016; p. 070017. Available online: https://alternativeenergy.procon.org/ sourcefiles/avian-mortality-solar-energy-ivanpah-apr-2014.PDF (accessed on 12 July 2018).

15. Walston, L.J., Jr.; Rollins, K.E.; LaGory, K.E.; Smith, K.P.; Meyers, S.A. A preliminary assessment of avian mortality at utility-scale solar energy facilities in the United States. Renew. Energy 2016, 92, 405-414. [CrossRef]

16. Aman, M.M.; Solangi, K.H.; Hossain, M.S.; Badarudin, A.; Jasmon, G.B.; Mokhlis, H.; Bakar, A.H.A.; Kazi, S.N. A review of Safety, Health and Environmental (SHE) issues of solar energy system. Renew. Sustain. Energy Rev. 2015, 41, 1190-1204. [CrossRef]

17. Turney, D.; Fthenakis, V. Environmental impacts from the installation and operation of large-scale solar power plants. Renew. Sustain. Energy Rev. 2011, 15, 3261-3270. [CrossRef]

18. Gasparatos, A.; Doll, C.N.; Esteban, M.; Ahmed, A.; Olang, T.A. Renewable energy and biodiversity: Implications for transitioning to a Green Economy. Renew. Sustain. Energy Rev. 2017, 70, 161-184. [CrossRef]

19. García-Garrido, E.; Lara-Santillán, P.; Zorzano-Alba, E.; Mendoza-Villena, M.; Zorzano-Santamaría, P.; Fernández-Jiménez, L.A.; Falcea, A. Visual impact assessment for small and medium size PV plants. Adv. Power Energy Syst. 2012, 57-61.

20. Chiabrando, R.; Fabrizio, E.; Garnero, G. On the applicability of the visual impact assessment OAISPP tool to photovoltaic plants. Renew. Sustain. Energy Rev. 2011, 15, 845-850. [CrossRef]

21. Chiabrando, R.; Fabrizio, E.; Garnero, G. The territorial and landscape impacts of photovoltaic systems: Definition of impacts and assessment of the glare risk. Renew. Sustain. Energy Rev. 2009, 13, 2441-2451. [CrossRef]

22. EC. COM 271 final. Renewable Energy: A major player in the European energy market. Commun. Comm. Eur. Parliam. Counc. Eur. Econ. Soc. Comm. Comm. Reg. 2012, 2, 14.

23. Guvernul României. OU nr. 24/30 Martie 2017 Privind Modificarea și Completarea Legii nr. 220/2008 Pentru Stabilirea Sistemului de Promovare a Producerii Energiei din Surse Regenerabile de Energie și Pentru Modificarea Unor Acte Normative, Monitorul Oficial nr. 224 din 31 Martie 2017; Guvernul României: Bucharest, Romania, 2017.

24. Papatulică, M.; Prisecaru, P. Dinamica Energiilor Regenerabile în UE şi România. In Studii Economice; Academie Română, Institutul Naţional de cercetări Economice: Bucharest, Romania, 2013; Volume 2, p. 28. Available online: http://www.studii-economice.ro/2013/seince130220.pdf (accessed on 8 June 2018).

25. Guvernul României. Ordonanta de Urgenta 79/2013; I, no. 390/June 2013; Monitorul Oficial: Bucharest, Rumania, 2013.

26. Mocanu, I.; Mitrică, B.; Persu, M. Consequences of setting up photovoltaic parks-related Land use/land cover changes in Giurgiu County rural area (Romania). Carpath. J. Earth Environ. Sci. 2015, 10, 2015-2209. 
27. Popovici, E.-A.; Mitrică, B.; Mocanu, I. Land concentration and land grabbing: Implications for the socio-economic development of rural communities in south-eastern Romania. Outlook Agric. 2018, 47, 204-213. [CrossRef]

28. Bringham, M. Just hungry? Analyzing the Relationship Between Land Concentration and Food Insecurity; Department of Sociology and Political Science, Norwegian University of Science and Technology, NTNU: Trondheim, Norway, 2003. Available online: www.brage.bibsys.no/xmlui/bitstream/handle/11250/268045/ 123129_FULLTEXT01.pdf?sequence11\&isAlowed1y (accessed on 7 November 2018).

29. Adevărul, Bomba Socială din Spatele Certificatelor Verzi. 2014. Available online: https://adevarul.ro/ economie/stiri-economice/bomba-sociala-spatele-certificatelor-verzi-5321e5f20d133766a8df3f29/index. html (accessed on 8 November 2018).

30. Mocanu, I.; Dumitraşcu, M.; Mitrică, B.; Grigorescu, I.; Şerban, P.-R.; Dumitrică, C. Solar Energy Industry as a Part of the Romanian Renewable Energy Industry: A Multi-Level Territorial Approach. Ann. Valahia Univ. Geogr. Ser. 2018, 18, 92-106.

31. Colesca, S.E.; Ciocoiu, C.N. An overview of the Romanian renewable energy sector. Renew. Sustain. Energy Rev. 2013, 24, 149-158. [CrossRef]

32. Oprea, C. Radiaţia Solară, in Vol. Clima României, Ed.; Academiei Române: Bucureşti, Romania, 2008; pp. 47-94.

33. Available online: http://version1.sistemulenergetic.ro/ (accessed on 22 June 2018).

34. Transelectrica. Puteri Totale pe Judete si tip de Sursa de Energie. pp. 1-8. Available online: http://www. transelectrica.ro/documents/10179/32316/7productie21.pdf/f0e4a9cc-42e5-4d07-9189-e421659664c7 (accessed on May 2018).

35. Posea, G.; Iordan, I. Câmpia Română. Caracterizare Generală. In Geografia României, Câmpia Română, Dunărea, Podişul Dobrogei, Litoralul Românesc al Mării Negre şi Platforma Continentală; Editura Academiei Române: Bucureşti, Romania, 2005; pp. 27-31.

36. Bălteanu, D. Unităţile de relief. In România, Natură şi Societate; Bălteanu, D., Dumitraşcu, M., Geacu, S., Mitrică, B., Sima, M., Eds.; Editura Academiei Române: Bucureşti, Romania, 2016; pp. 82-101.

37. Bogdan, O. Clima. In Geografia României, Câmpia Română, Dunărea, Podişul Dobrogei, Litoralul Românesc al Mării Negre şi Platforma Continentală; Editura Academiei Române: Bucureşti, Romania, 2005; pp. 47-64.

38. Dumitrescu, A.; Bîrsan, M.-V. ROCADA: A gridded daily climatic dataset over Romania (1961-2013) for nine meteorological variables. Nat. Hazards 2015, 78, 1045-1063. [CrossRef]

39. Soare, E. Durata de strălucire a Soarelui. In Clima României, Editura Academiei Române; Sandu, I., Pescaru, I., Poiană, I., Geicu, A., Cândea, I., Țâștea, D., Eds.; Editura Academiei Române: București, Romania, 2008; pp. 105-114.

40. Available online: http://re.jrc.ec.europa.eu/pvgis/ (accessed on 8 September 2018).

41. Available online: http://www.minind.ro/domenii_sectoare/energie/studii/potential_energetic.pdf (accessed on 11 June 2018).

42. Gunerhan, H.; Hepbasli, A.; Giresunlu, U. Environmental impacts from the solar energy systems. Energy Sources Part A Recovery Util. Environ. Eff. 2008, 31, 131-138. [CrossRef]

43. Chaurey, A.; Kandpal, T.C. Assessment and evaluation of PV based decentralized rural electrification: An overview. Renew. Sustain. Energy Rev. 2010, 14, 2266-2278. [CrossRef]

44. Guerin, T. Using agricultural land for utility-scale photovoltaic solar electricity generation. Agric. Sci. 2017, 29, 40.

45. Armstrong, A.; Waldron, S.; Whitaker, J.; Ostle, N.J. Wind farm and solar park effects on plant-soil carbon cycling: Uncertain impacts of changes in ground-level microclimate. Glob. Chang. Biol. 2014, 20, 1699-1706. [CrossRef] [PubMed]

46. Mocanu, I.; Mitrică, B.; Vârdol, A.; Serban, P. Territorial patterns of socio-economic development in the Romanian Danube valley. Forum Geogr. 2015, 14, 164-177. [CrossRef]

47. Mitrică, B.; Mocanu, I.; Dumitraşcu, M.; Grigorescu, I. Socio-economic disparities in the development of the Romania's border areas. Soc. Indic. Res. 2017, 134, 899-916.

48. APM Giurgiu. Decizie No. 1022 din 24.02.2012, S.C. LONG BRIDGE MILENIUM S.R.L Stăneşti; Agenţia pentru Protecţia Mediului: Giurgiu, Romania, 2012. 
49. APM Giurgiu. Proiectul Deciziei Etapei de incadrare Nr. 1581 din 02.03.2012; SC BORRA ENERGY PLANT (SRL): Izvoarele, Romania, 2012.

50. Ministerul Energiei. Romanian Energy Strategy 2016-2030, with an Outlook to 2050; Ministerul Energiei: Bucureşti, Romania, 2016; pp. 1-116. Available online: http:/www.mmediu.gov.ro/app/webroot/ uploads/files/2017-03-02_Strategia-Energetica-a-Romaniei-2016-2030.pdf (accessed on 17 September 2018). (In Romanian)

C 2019 by the authors. Licensee MDPI, Basel, Switzerland. This article is an open access article distributed under the terms and conditions of the Creative Commons Attribution (CC BY) license (http://creativecommons.org/licenses/by/4.0/). 